I Universidad Alberto Hurtado (UAH), Departamento de Sociología, Santiago, Chile tundurraga@uahurtado.cl

https://orcid.org/0000-0003-4267-5826

I I Universidad Alberto Hurtado (UAH), Departamento de Sociología, Santiago, Chile marquelipe@gmail.com

https://orcid.org/o0oo-0002-2392-288X

Tomás Undurraga'

Felipe Márquez"

\title{
THE UNFINISHED DEVELOPMENT OF THE FRONTIER: A KARL POLANYI READING OF THE CONFLICT BETWEEN THE FORESTRY INDUSTRY, MAPUCHE COMMUNITIES AND THE CHILEAN STATE ${ }^{1}$
}

On January 5, 20I2, the Casa Piedra plantation of Forestal Mininco, Araucanía, suffered an arson attack that ended the lives of seven firefighters. On January 4, 20I3, the Luchsinger-Mackay family burned to death inside their home in Vilcún, Araucanía. Both fires were attributed to Mapuche communities acting in retaliation for the murder of a Mapuche man, Matías Catrileo, who was killed on January 3, 2008 by police officers in contested "reclaimed" lands in Vilcún. On November I4, 20I8, another Mapuche man, Camilo Catrillanca, was shot dead in Temucuicui, Araucanía, by members of the special operations police dispatched to control the "Mapuche conflict." The scene is familiar: confrontations between state police and members of the Mapuche community in invaded estates, police helicopters flying over Temuco, forced entry of Mapuche communities, and forestry companies, subcontracted workers, prosecutors, and the government making remarks about 'terrorism' in the media (López \& Nitrihual, 20I4: I5).

These clashes and the deaths they have often produced not only reflect the recent growing militarization of the Araucanía region: they echo a longstanding conflict between the Mapuche people and the Chilean State, a conflict that has intensified with the expansion of the forest industry during the last 40 years. The occupation of forestry estates, the blocking of roads and the burning of logging trucks, churches and schools are among the contentious actions instigated by Mapuche activists who have mobilized over land right issues, 
human rights issues, and identity politics. According to the Mapuche Data Project (2019), between I 990 and 2016 there were seven hundred and ninety-eight events involving attack and/or invasion of forestry estates and private lands reported in the press.

These disputes take place in the frontier region (Klubock, 20I4), the territory between the Bío-Bío and Toltén rivers, today made up of the regions of Bío-Bío and Araucanía. This was the historical border established between the invading Spaniards and the Mapuche people since the Spanish colonization of Chile (XVII century), and then finally seized by the Chilean State with the military occupation of $1860 .{ }^{2}$ In fact, this further invasion took several decades and meant the slow dispossession of indigenous lands, the State imposition of special "enclosed" lands for the Mapuche people, and the deprivation of the Mapuche people of their historic freedom of movement in the forests. The State handed over frontier lands to companies that promised to bring settlers and develop the territory, contributing to its colonization. It aimed to install economic activities as a way of domesticating "the wild territory," an expression in which this wilderness was understood to refer to both the native forest and the Mapuche people themselves (Bengoa, 2008). To integrate settlers and the indigenous population, the State provided public services, such as hospitals and schools, in the main towns, and developed rail, port and electricity infrastructures (Lima-Toivanen, 20I 2).

Despite these efforts, the conflicts in the frontier territory remain active. Indeed, they have intensified in recent years following increased militarization of the area by the Chilean State, which, in its eagerness to protect timber production and private property, has augmented its use of force to regulate relations of production. The State has prosecuted multiple Mapuche activists for occupying estates through application of its newly ratified anti-terrorism law (Pineda, 20I4; Pairicán, 20I4). This law has been widely criticized by human rights organizations for its overly broad definition of terrorism and for insufficient guarantees of due process.

The frontier disputes are not new. They have been documented and explored from different academic perspectives, including the environmental history of southern Chile (Camus, 2006), the ecological conflict surrounding forests in Chile's frontier territory (Klubock, 20I4), the reconstruction of Mapuche history (Bengoa, I992, 2008; Foerster \& Montencino, I988), and the loss of native forests (Elizalde Mac-Clure, I970). More recently, ethnographic research has studied Mapuche land claims (Di Giminiani, 2018), capitalist expansion in Chile's southern forests (Skewes, 20I9), the fraught relationship between Mapuche communities and the forestry industry (Torres-Salinas et al., 20I6), and forest certification and labor practices within the forestry industry (Henne, 2015; Tricallotis, 2016).

This article explores the frictions (Tsing, 2005) between the Chilean State, Mapuche communities, and the forestry industry, taking Polanyi's reading (200I) 
of capitalist expansion as its point of departure. In line with recent literature inspired by Polanyi concerning the effects of and reactions to neoliberalism (Dale, 20I0; Feinig, 20I8; Goodwin, 20I8; Sandbrook, 20I I), different researchers have investigated conflicts of indigeneity (Li, 20IO), capitalism's global transformations (Gemici \& Nair, 20I6; Halperin, 20I8), and state protection and development policies (Hart, 200I). We propose a Polanyi-inspired reading of the frontier conflicts that stresses the historical-institutional dynamics of the relations between the State, the forestry industry, and civil society. As Triglia (2002) and Block and Evans (2005: 506) point out, this means paying special attention to "the activity of real human beings with associational ties forged out of kinship, neighborhood, ethnicity, religion, class, and other identities." This reading sheds light on the Mapuche counter-movement not only against a forestry industry that transformed the landscape, limiting Mapuche access to lands and forests, but also against a modernization process led by the Chilean State that eroded traditional Mapuche institutions and offered them integration merely as "poor peasants." The Mapuche reactions can be seen as responding both to their economic pauperization and to political and sociocultural structures that have not played in their favor.

Based on historical documents, press material, and the specialized literature, this article unpacks the current conflict on the frontier within a historical perspective. The article is also informed by ethnographic research conducted in 2019 within the main forestry industry in Chile, as well as by fifteen interviews with regulators, scholars, and forestry engineers.

We argue that the rising violence in this zone not only reflects the State's growing militarization of the area, but also to the counter-movement (Polanyi, 200I) of social protection initiated by the Mapuche people. We argue that the constant frontier violence evinces an unfinished "development" of this territory. The Chilean State encounters difficulties in governing this zone, partly because it has been unable to integrate Mapuche communities into a type of development from which they could benefit. The expansion of the forest indus try, paradoxically, has to some extent played the role that the State has failed to play in the frontier territory. In Granovetter's terms (I985), it is an embedded industry in these territories. It provides jobs, transforms the territory, and gives shape to local institutions. Yet the economic wealth produced by this industry has not for the most part trickled down to indigenous people in this area. Further, the industry has shown little recognition of Mapuche institutions, language, and territorial rights. While it is true that many Mapuche work for the industry as subcontractors in the logging and haulage of timber, the Mapuche remain the population with the highest levels of regional poverty. ${ }^{3}$ The exponential growth of forestry plantations has not only meant the commodification of land and labor in the area but also a huge geographical transformation, replacing native forests and agricultural lands with exogenous trees. ${ }^{4}$ Large-scale forest 
plantations have transformed vast territories into private monocrops, colliding with the "ontological" ways in which Mapuche communities traditionally inhabited these areas (Di Giminiani, 20I8). This is not to say that all Mapuche communities seek to maintain their historical mode of livelihood, freely moving through forests between winter and summer, gathering fruits and wood (Skewes, 20I9). Yet the deprivation of access to lands and economic progress, as well as low recognition of Mapuche institutions and traditions, have helped radicalize local forms of Mapuche protest.

The article is organized as follows. First, it reconstructs the role played by the forest industry in the Chile-Mapuche conflict and the changing relationship between the State, the forestry industry, and civil society in three periods: the occupation by the State of the frontier territory (I860-I930); State-guided afforestation (I930-I990); and the consolidation of the free-market forestry industry (I990-2020). Second, we examine the current conflicts surrounding the forest industry, taking five of Polanyi's central concepts as a guide: the role of the "enclosures" at the dawn of capitalism; the embedded nature of the economy in society; the social consequences of commodifying land; the laissezfaire ideology and its attempt to make invisible the role of the State in producing markets; and the protective reactions that societies generate against the market's advances. Finally, the article concludes by discussing the environmental and social consequences of the inorganic growth of the forest industry in the frontier region in light of Polanyi's reading.

\section{THE FORESTRY INDUSTRY IN THE LONG HISTORY OF THE FRONTIER}

The forestry industry is today at the forefront of economic growth in centralsouthern Chile. The industry stands out for the vast extent of its plantations (more than three million hectares) and for the concentration of corporate power it represents: two large consortia (CMPC and Arauco) control over $80 \%$ of forestry production. The forestry industry expanded with special vigor during the military dictatorship (I973-I990), when large financial consortia acquired State land and companies. In 1974 the Pinochet dictatorship decreed law no. 70I(dl 70I) on Forest Development, which established generous bonuses and tax exemptions for forest industry plantations (Kurtz, 200I). In practice, State support led to the multiplication of pine and eucalyptus plantations, homogenizing the landscape, and reducing native forests. Exotic plantations increased exponentially from 300,000 hectares in 1970 to $3,047,000$ hectares in 2016 (CONAF, 20I6), significantly altering land use and the environment with monocultural crops. Forest development in Chile, however, has a long history dating from the frontier's military conquest in I860, a history that we reconstruct in three periods. 


\section{LAND DISORDER (1860-1930)}

Spaniards and Mapuche communities established a mutually respected border on the Bío-Bío River in I598, when Spanish forces were defeated in the Battle of Curalaba. For centuries, trade was regular across both sides of the river and special "parliaments" were enacted that provided a political mechanism to deal with differences (Bengoa, 2008: 35). This balance of power was broken, however, with the independence of Chile in $18 \mathrm{I} 8$, which unleashed growing demand for Mapuche lands. In I845, the Chilean Congress enacted the Colonization Law, which sought to attract foreign and national immigrants to populate "vacant" land south of the Bío-Bío River. There was no such vacant land, however, as it was amply populated by Mapuche peoples. The arrival of foreign settlers resulted in the Mapuche uprising of I859, which burned forts and settlements south of the Bío-Bío (Bengoa, 2008: I5I-I70). In this context, the Chilean State began the occupation of Araucanía in I86I, founding new cities and militarily occupying the frontier. This new attempt at occupation posed the political challenge of conquering what was historically an indomitable territory, along with the physical challenge of domesticating a dense and intractable jungle.

As part of the military offensive, the Chilean State enacted the Law of Indigenous Reductions in I866. This law sought to confine Mapuche property to stable settlements within known limits. The Mapuche, however, were not accustomed to using land in compliance with the norms of fixed private property. Instead, they were transhumant, migrating with their herds grazing in high areas in the summer and low areas in the winter (Bengoa, 2008; Pinto, 20I2). In practice, these attempts to reduce indigenous lands to settlements reflected an effort by the Chilean State to subdue the Mapuche people (Almonacid, 2009: 8). The Colonization Law (I845), which gave land to those who occupied and worked the land, and the Reductions Law (I866), which formalized the ownership of land by Mapuche families, led in practice to two parallel property regimes that contradicted each other. The existence of property vacuums generated situations in which Mapuche lands were appropriated by settlers (Klubock, 20I4: 48). Although complete Mapuche military defeat came in the I89os, there was still little certainty about where the land of each owner began and ended at the dawn of the twentieth century. This meant "the failure of state colonization officials to protect the borders of Mapuche reductions and settle pioneers or occupants in small plots" (Klubock, 20I4: 54), increasing the conflicts resulting from the usurpation of both State and indigenous lands.

The attempted occupation of the frontier at this time also led to ecological and social disasters. At the beginning of the twentieth century, nine million hectares of native forest had been destroyed by fire (Klubock, 20I4: 69), used to replace the forests with wheat and other agricultural crops, which over the years left the soil eroded (Camus, 2006). This ecological disaster was accompanied by the social tragedy of indigenous land reductions, producing a 
confined population that became impoverished by its new social and natural living conditions (Bengoa, 2008). At this time, the State gave away a large amount of land through concessions to private companies with the aim of settling immigrants in the territory. This strategy, however, failed in many respects because companies often found it difficult to successfully attract and settle immigrant families, and instead cut down native forests for their own benefit. The Forestry Law of I 925 and the Southern Property Law of I93 I were State efforts to resolve the aforementioned property issues, as well as the problems of environmental erosion, all the while imposing greater order on the frontier.

\section{"STATE-GUIDED" FORESTRY AND INDIGENOUS POLITICS (1930-1990)}

The Chilean forestry industry gained strength at the beginning of the twentieth century by virtue of a stronger alliance between the State and landowners. The State promoted afforestation by building pulp mills and ports, installing rail lines, and improving sawmills. Influenced by the forestry science developed in Europe (Mathews, 20II), it committed to a plan for afforestation with exotic species, especially the Monterrey pine. The State-landowner alliance had a double purpose: on the one hand, it aimed to build a modern forestry industry that would develop the area and protect the soils from increasing erosion. On the other, it sought to establish greater order in what had been seen as a "wild territory." Echoing Scott (I998), we could say that the Chilean State sought to simplify and make readable an untamed territory of thick arboreal jungle through scientifically planned plantations, reinforcing the principle of ownership. Afforestation would make possible the quantification and statistical management of the territory, as well as limiting the free movement of the Mapuche through the forests (Klubock, 20I4: I9-20). It is worth mentioning, however, that these State efforts were based on an idea of modernization that promoted a shift of norms from traditional rules and roles toward a more "rational," secularized normative framework (Germani, I98I) that failed to recognize the value of Mapuche institutions, lands, and ways of living.

Between 1930 and 1970 the State was primarily interested in transforming forests into commodities. Through forestry inventories, scientific trials, resources for machinery, and large-scale afforestation, the Corporación de Fomento de la Producción (CORFO) laid the foundations for forestry development (Nazer, Camus \& Muñoz, 2009). The developmentalist approach led by the State (CORFO) prompted landowners to exert controlled exploitation of native forests and to plant coniferous trees from North America (Camus, 2006). These species were more readily planted on eroded land, grew easily, and required less care than other species.

The strengthening of the forestry industry, however, generated new territorial disputes with indigenous communities. By way of a palliative, in 1952 president Ibañez del Campo appointed the indigenous leader Venancio Coñoepán 
as minister of Land and Colonization (Foerster \& Montesinos, I988), and in 1953 he founded the National Directorate of Indigenous Affairs. Despite these efforts to appease Mapuche grievances through symbolic concessions, the conflict over land remained lively (Pinto, 20I2). A decade later, through the I967 Peasant Unionization Act (Ley de Sindicalización Campesina), the farm labor organization achieved formal recognition for the first time, which allowed for more joint negotiations between landowners and peasants (Klubock, 20I4: I83). At the end of I 960 s, though, stimulated by the land reform then underway across the country, peasant farmers and Mapuche communities in Southern Chile initiated a wave of land invasions, demanding both the restoration of "usurped land" to Mapuche communities and the expropriation and redistribution of private estates to their workers (Klubock, 2014: 210).

The Chilean socialist agenda, led by president Allende (I970-I973), intensified pressure for profound social structural change. The Popular Unity (UP) program entailed the nationalization of key industrial sectors, including copper mines and banks, and deepening land reform (Taylor 2006). In the forestry sector, the Chilean State increased control over planted farms and sawmills, such as the emblematic Panguipulli Forest and Logger Complex (Skewes, 2019). In I973, CORFO controlled most of the pulp and paper plants, and possessed a majority stake in large paper companies (Lima-Toivanen, 20I 2). During the UP, land invasions increased throughout southern Chile, along with a demand for more radical agrarian reforms.

The I973 coup d'état meant a radical shift in terms of official policy towards Mapuche communities and forestry plantations. General Pinochet's regime sought to accelerate the process of land division and auction and to end the indigenous legal status (Boccara \& Seguel-Boccara, I999: 767). His regime revoked the agrarian reform and peasant unionization laws, auctioned most of its industrial facilities and forest plantations, and pushed relations of production in a neo-liberal direction (Lima-Toivanen, 20I2). Forest policy was radically transformed by the $\mathrm{dl} 70 \mathrm{I}$ enacted in 1974 . This decree stimulated the private development of the forestry industry with a system of forest bonuses that covered $75 \%$ of the value of land afforestation. It also excluded forest land from taxes and allowed export of unprocessed timber resources. These incentives produced the desired effect, generating exponential growth of forest plantations. While in 1970 there were 300,000 hectares of planted trees in Chile, by I 990 there were I,460,530 hectares (ODEPA, 20I 2). In sum, Pinochet's dictatorship (I973-I990) promoted a significant rearrangement of the State's economic and social policies, with an emphasis on market-oriented solutions to public issues and on the exportation of raw materials. 


\section{MEDIATOR STATE, IDENTITY POLITICS AND CONTEMPORARY CONFLICT BE- TWEEN THE MAPUCHE PEOPLE AND THE FORESTRY INDUSTRY (1990-2020)}

Neoliberal policies in Chile, as in the rest of Latin America, Africa, and Asia, endorsed strategies of de-industrialization that focused instead on primary export industries (such as agriculture, forestry, aquaculture, and mining) in the search for "comparative advantages" (Undurraga, 20I5). While industrialization programs that had been emblematic of the developmentalist state until the I970s waned in countries such as Brazil, Argentina and Mexico, Chile turned towards a strategy of complete de-industrialization (Domingues, 2008). The reprimarization of local economies implied a renewed pressure on natural resources. As Svampa (201 3: 34) points out, this neo-extractivism installs a vertical dynamic that bursts into territories, affecting regional economies, destroying biodiversity, and dangerously deepening the process of land grabbing by expelling or displacing rural, peasant or indigenous communities. The expansion of the forestry industry in Chile is an iconic example of such neo-extractivist pressures on land and people.

In I990 the Chilean forestry industry was already highly concentrated (Lima-Toivanen, 20I2), generating environmental concerns both in Chile and overseas (Auld, 20I4). With the return to democracy, Mapuche territorial claims increased, connected to new environmental claims related to protecting biodiversity and the remnants of native forest (Skewes, 20I9; Di Giminiani, 20I8). Several Mapuche communities regrouped, forming movements dedicated to land recovery and the sustainable use of native forests, proposing an alternative to free-market forest development (Klubock, 20I4: 25). Identity politics and indigenous pride took on new life with the commemoration of the Fifth Centenary of America's discovery (I992), challenging the paradigm of a mono-cultural nation (Foerster \& Vergara, 2002: 79). President Aylwin's government (I990I994) channeled these pressures and created the National Indigenous Corporation (CONADI), a conflict-mediating institution that administers the Fund for Indigenous Lands and Waters, aimed at buying land in disputed areas from private individuals to be transferred to indigenous communities. CONADI also began promoting State initiatives for the development of indigenous communities and their cultural and economic integration into national life. These initiatives include student scholarship programs aimed at educating Mapuche leaders, the development of bilingual schools in the frontier region in which the Mapudungun language is taught alongside Spanish, supporting indigenous entrepreneurs in tourism and ecological activities, as well as management support for the development of local forestry plantations, among others.

An emblematic case of Mapuche territorial claims was the 1992 invasion of the Quinquén estate instigated by the Meliñir community. They accused the Galletue forestry company of illegally cutting Araucaria pine trees. The invasion was settled in the supreme court, which recognized the company's right to the land, and ordered the community to end its seizure and leave the area (Klubock 
20I4: 279). This resolution raised alarm and indignation. Mapuche comuneros blocked roads in Lonquimay to prevent the entry of trucks, while the indigenous community appealed to its historic grazing rights in the forest. There was a fresh push to link indigenous land claims to the conservation language echoed by the NGO World Wildlife Fund (WWF), which was concerned about the illegal felling of protected trees like the Araucaria (Bengoa, I992). President Aylwin declared the land near Lake Galletué a national reserve. Finally, in 2007 the Meliñir community managed to acquire property titles on the Quinquén estate and developed an ecotourism project promoted by the WWF.

Land claims appealing to Chile's Indigenous Law were increasingly lodged over contested lands where forestry or agricultural companies were operating (Foerster \& Vergara, 2002: 83). Despite the State's efforts to purchase land and mediate relations, on October I2, I 997 two hundred Mapuche blockaded the road in Lumaco and cut off access to the Pidenco estate owned by Forestal Arauco (Pairicán, 20I4: 4I). A month later the demonstrations took an unexpected turn, burning infrastructure, machinery, and trucks. From the late I99os, the Chilean-Mapuche conflict entered a new stage. The pictures of burnt forestry machinery became a symbol of protest for activist groups. An image of the Mapuche people as a danger to society was revived in the press, linked to so called "terrorist" activities. The democratic governments from the I 990 onwards maintained two parallel strategies in response to this conflict. On the one hand, they sought to purchase land for distribution via CONADI as reparation for the historical debt to indigenous communities and financed programs aimed at improving the situation of the Mapuche both culturally and economically. On the other hand, these governments used repressive tactics to assure the production of forest plantations, transforming areas of southern Chile into armed camps patrolled by State police (Klubock, 2014: 293).

\section{THE UNFINISHED DEVELOPMENT OF THE FRONTIER:}

\section{A POLANYI-STYLE READING}

In what follows we pay greater attention to the current conflict between the Chilean State, Mapuche communities, and the forestry industry, offering a historical interpretation based on five interpretative insights from Karl Polanyi's reading of capitalist transformations. These are: the role of the "land enclosures" on which the Chilean forestry industry is founded; the embedded nature of the economy in society and how the legitimacy problems faced by the forestry industry are partly explained by its attempt to dissociate itself from the territory in which it operates; the social consequences of the forest industry's commodification of land on Mapuche communities; the laissez-faire ideology promoted by the forestry industry, and its attempt to make invisible the role of the State in its development; and the protective reactions that Mapuche communities generate against the forestry industry's advances. 


\section{LAND ENCLOSURE'S ROLE AT THE DAWN OF CAPITALISM}

The history of the forest industry and the conquest of the southern territory of Chile echo similar processes described by Polanyi at the dawn of capitalism, such as the enclosure of communal lands in seventeenth century England. Homologous processes include the conquest of the West and the extermination of natives in North America, and the "conquest of the desert" and the indigenous massacre in the Argentine pampas. In The great transformation, Polanyi (200I: 35) argues that the industrial revolution in England represented a radical break in the history of mankind, not only because technological progress triggered "an almost miraculous fact of improvement in production tools", but also because the industrial revolution implied profound changes in the organization of human societies. The enclosure of common lands, together with governmental changes in State intervention and labor relations, transformed societies traditionally characterized by a close connection between people and land into societies where land and property were concentrated in a few hands. The enclosures in England "liberated" people from the countryside to provide labor to the nascent industries. In this process, market exchange penetrated relationships that until then had been based on social and political factors. The forced exodus of peasants to the city produced a serious social dislocation.

The development of the forestry industry in Chile was instrumental in the conquest of the southern frontier and was based on a process similar to the one Polanyi describes for the English enclosures. Converting the frontier territory into a commodity was the primary way in which the State sought to secure its dominion. The State essentially attempted to "normalize" the land via the imposition of known limits and boundaries, the standardization of the soil, and other techniques designed to simplify the territory through standardization (Scott, I998). While the Chilean State aimed to integrate the frontier population through the provision of public services such as schools and hospitals, it also provided state incentives and low-cost auctions of forest land for the development of the forestry industry. From I930, large areas of land were purchased by economic groups, leading to the concentration of forest properties. These forestry companies began to restrict other economic activities, expel tenants from farms, buy land from peasants at low prices, and secure cheap labor for logging (Klubock, 20I4: 242). The colonization of the territory via the plantation of foreign species, however, was originally resisted by the rural poor, the Mapuche communities, land occupants, and forest debt-peonage workers; groups different from each other in many ways but who were lumped together as "peasants" by the State and the forestry enterprises.

The enclosure of planted territories was also accompanied by another enclosure: the creation of State national parks. In I 926 the first national park was created: Parque Vicente Perez Rosales. This form of enclosure also deprived indigenous communities of their access to forests that had been protected for 
conservation, preventing them from accessing the land to graze livestock or collect fruits and firewood (Skewes, 2019). In the Ránquil peasant rebellion in I934, for example, hundreds of indigenous people, supported by the Workers Federation, rose up against their lost access to forests. The first man killed by the popular movement was the park ranger who guarded the Alto Bío-Bío reserve and had prevented them from cultivating crops and pasturing livestock on the land they had traditionally occupied in the mountain range. The police response to this rebellion was brutal, initiating a violent crackdown that left more than thirty dead (Klubock, 20I4). This was just one of several peasant protests, which, from the I920s onwards, flared up against the enclosed territories.

Land enclosures played a fundamental part of the development of the forest industry in Chile. Consonant with the neo-extractivist pressures stressed above, Cotula (2013) points out that today's global land rush impelled by the forest industry continues to bring competing land claims into conflict, creating ongoing tensions between more commodified and more "socially embedded" conceptions of land. The Chilean case is paradigmatic of the former.

\section{THE EMBEDDED NATURE OF THE ECONOMY IN SOCIETY}

Historically, markets had always been embedded in society, Polanyi argues. Economic exchange in all previous economic systems rested on wider social institutions. Economic systems up until feudalism in Western Europe were all organized either on the principle of reciprocity, or on redistribution, or on householding, or on some combination of the three. These forms of economic organization were based around the social aspects of the society; that is, they operated in and were explicitly tied to social relationships. The capitalist attempt to control the economic system exclusively in market terms meant the running of society as an adjunct of the market, "disembedding" the economy from society.

Polanyi's claim concerning the embeddedness of economic life in broader social relations has several antecedents (Dale, 20I0: I90). He took from Marx the idea that economic behavior cannot be studied in isolation from society. In line with Tonnies, Polanyi understands the economy in capitalist societies to be instituted in a singular historical form, which is distinguished in the transition from community to society (Gemeinschaft und Gesellschaft). From Weber, he elaborates the claim that economic behavior is anchored in the cultural arena of customs, language, and collective ethos, and that the ethics of capitalism contrasts sharply with that of previous systems. Polanyi's thesis concerning embeddedness has attracted fresh interest in recent years, generating an intense debate about the relationship between economic action and social structure. While for Granovetter (1985) this embeddedness is manifested in networks in which agents are immersed, and from which economic action emerges, for Beckert (2007) Polanyi's idea of embeddedness is anchored in an institutional analysis in which markets are more than mere networks: they are social structures from which markets emerge that, in turn, determine how networks are structured. 
How to understand the embeddedness of the forestry industry in Chilean society? The "free market" approach incentivized by the State (dl 7oI) since I974 led to a huge expansion and concentration of pine plantations owned by two Corporations - Arauco \& CMPC - covering three million hectares, mostly located in former Mapuche territories. A large proportion of this production is dedicated to exports. From the perspective of the forestry sector, the industry has been a dynamic force for economic development. Yet the industry suffers an important problem of legitimacy, related both to the historical territorial conflicts and to the large-scale neglect of the communities in which it operates. Many plantations are resisted by Mapuche and local communities, who claim that their land has been illegally usurped and are fearful of the natural disasters, such as droughts and forest fires, that are often triggered or worsened by these plantations (Torres-Salinas et al., 20I6). While there are a few local Mapuche producers who own small tree plantations, the Mapuche participation in forestry generally takes the form of precarious, sub-contracted low-wage labor. Put another way, the managerial cadres of both Arauco and CMPC contain no Mapuche people.

When faced with the problem of legitimacy connected to its land use, the forestry industry tends to blame the State. A representative of the industry explains: "there is a historical problem that has nothing to do with large companies, but with the Chilean State. Chile conquered these lands and took away the territory from people who lived here before. Large companies bought these lands from previous owners. Yet today a big corporation is an easy target to point your finger at" (interview, July 20I9). What the industry representative does not acknowledge is that its mode of production has a huge environmental impact and that the wealth produced has not "trickled down" to the regions where it operates. This is an industry more embedded in global markets than in regional development. It speaks to and emulates the customs, language, and ethos of export forestry markets more than it does that of local communities. Interestingly, the massive forest fires of recent years, particularly the megafires of 2017 which burned down 570, I97 hectares (González et al., 2020), have become such a growing threat to the sector that the main forestry companies have begun working collaboratively with local government and small owners on prevention measures (for example, the Red de Protección Comunitaria program). Megafires have become an opportunity for the forestry industry to establish greater local embeddedness.

\section{THE MORAL DEGRADATION ASSOCIATED WITH COMMODIFYING LAND AND LABOR}

According to Polanyi, markets cannot function in the absence of a parallel system of social relationships; the neoliberal concept of a "self-regulating" market is a myth (Granovetter \& Swedberg, I992). In this circumstance, "instead of the economy being embedded in social relations, social relations are embedded in the economic system" (Polanyi, 200I: 60). Human society, as a consequence, 
becomes an accessory of the economic system. To allow market mechanisms to become the sole director of the fate of human and natural beings, Polanyi warned, would result in the destruction of society. "Robbed of the protective covering of cultural institutions, human beings would perish from the effects of social exposure; they would die as the victims of acute social dislocation through vice, perversion, crime and starvation" (Polanyi, 200I: 76).

Despite capitalism's unprecedented capacity to create wealth and improve economic conditions, Polanyi stresses that the implementation of freemarket capitalism in the nineteenth century also produced huge dislocation and suffering, spreading inequality, human misery, and environmental degradation. Polanyi depicts the "destructive spirit" of capitalism in the "satanic mills' of the Industrial Revolution, which he describes as machines that physically destroy men and transform their surroundings into a new type of wilderness (Undurraga, 20I4). So called "self-regulated" markets are a threat to humans and nature alike, destroying the old social fabric and transforming men into "faceless masses." The market economy, in Polanyi's reading, denies authentic individual responsibility, undermines community, and obstructs incentives for moral behavior. Human labor is transformed into a commodity and society deteriorates into a more unequal condition. As made evident by the Industrial Revolution, workers were physically dehumanized, and the owning classes became morally tainted. "Liberalism," according to Polanyi, had created wealthy yet ethically impoverished societies. While for Mandeville the free market system magically converts private vice into public virtue, for Polanyi the alchemy is demonic, transmuting private virtue into public vice (Dale, 2010).

The social consequences of the free-market forest industry in Chile and its commodification of land - and partly of labor - bear out some of Polanyi's grimmest predictions. This industry is the second largest producer of wealth in Chile - after mining - and, without doubt, that wealth has transformed the landscape and cities of central-southern Chile. A representative from the industry remarks: "Plantations have helped us solve poverty problems, generate 300,000 jobs, and extensive economic activity: banks, hotels, transporters, ports, many positive externalities. $8 \%$ of Chile's exports are wood products" (interview, June 20I9). Yet the regions from which the forest industry extracts its wealth remain among the poorest in Chile. They are the areas where social conflict, environmental erosion, and the difficulties of a fraying social cohesion are most clearly manifest. According to CASEN $2017,8.2 \%$ of the Chilean population lives in poverty, while in the Araucanía Region the figure is $17 \%$, and in the Bío-Bío region I3.I\%. The indigenous population has a greater tendency to be poor (Ministerio de Desarrollo Social Development, 2018). Furthermore, the forestry industry promotes a commodified approach to labor. Its production system is not based on the local labor force but rather on teams of subcontractors very often hired from abroad. One of the main demands made to the forestry cor- 
porations by local communities through the Red de Protección Comunitaria is to contract more local workers (interview, June 2020).

Environmentally speaking, the massive presence of monoculture plantations has triggered several criticisms. On the one hand, environmental experts accuse the forestry industry of complicity with recent mega-fires, depletion of waterways, and damage to biodiversity caused by the industry's use of pesticides. The replacement of the native forest - a natural barrier to fire - by plantations of exogenous and highly-flammable species such as pine and eucalyptus, combined with the drying out of watersheds due to the vast amounts of water absorbed by these species, have increased the occurrence of forest fires (Altamirano et al., 2013, González et al., 2020). On the other hand, the forestry industry is criticized for impoverishing the surrounding communities. Academics and activists discuss whether, how, and to what extent plantations reduce or maintain poverty. In defense of the forestry industry, scholars such as Nazif (20I4) point out that the frontier lands were already eroded by the exhaustive agriculture practiced by the poor communities who lived there before the forestry industry developed. Arguing against the forestry industry, Andersson et al. (20I6: I25) claim to show a positive correlation between the poorest areas and those areas with forest plantations, arguing that forestry monoculture fails to produce good jobs and has exacerbated rural poverty. Regardless of where the truth may lie on this question, forest commodification has not provided socially and environmentally responsible development in the territories it exploits.

\section{THE LAISSEZ-FAIRE IDEOLOGY AND THE ATTEMPT TO DENY THE STATE'S ROLE IN PRODUCING MARKETS}

According to Polanyi, the market economy was not "the natural evolution of trade and barter," as Adam Smith (I986) argued, but an eccentricity in history, the consequence of a particular political project guided by economic liberalism. Organizing economic life based on self-interest is, for Polanyi, unnatural. The two world wars, the spread of fascist regimes across Europe, and the Great Depression were, Polanyi argues, the unintended consequences of the liberal political economy. In The great transformation, Polanyi (200I) sought to explain the political turbulence and economic collapse of nineteenth-century civilization: after such a long period of relative peace and prosperity (I8I5-I9I4), why did Western nations take such a destructive path? The deep root of these crises, according to Polanyi, was "market utopianism." The attempt to universalize capitalist institutions at global level broke traditional societies and spawned contradictions that ultimately brought the system crashing down. One element of this market utopianism was to deny the State's role in producing markets. As an example, Polanyi evokes the cotton industry in England. In this case, the free market was not self-created but grew thanks to State protective mechanisms such as cotton tariffs, export bonds, and indirect wage subsidies. 
When we turn to examine the development of the free-market forest industry in Chile, Polanyi's critique of laissez-faire ideology appears germane. Like the cotton industry in England, the Chilean forest export boom was also created by State-led intervention (Kurtz, 200I). Despite the relentless discourse of the forest industry association Corporación de la Madera (CORMA) and its attempts to explain the sector's success through appeals to the role of the 'free' market, the State's role in the expansion of the forestry sector has, in fact, been fundamental.

The Chilean State has guided the forestry industry in different ways over various historical periods. The conquest of the frontier and the giving away of large territories of native forest for exploitation would have been inconceivable without the impulse of the State. "Rational" management of forests was also part of a State strategy to contain eroded soils, support industrialization, and control frontier territories, establishing boundaries between different properties. State incentives during the twentieth century were multiple: 30-year tax exemptions for those who assigned their land to afforestation (I93 I Forest Bonuses Law); the creation of forestry companies by CORFO; CONAF forestry agreements in I970; and $\mathrm{dl} 70 \mathrm{I}$ in I974. Belying the free-market discourse promulgated by the forestry industry today, the Chilean forest "miracle" was the product of sustained State intervention. The current police protection provided for forest production is another contribution made by the State. Moreover, the various reparation actions made by the Chilean State to the Mapuche during the post-dictatorship era - buying lands, supporting indigenous education, and eco-tourism programs - are all State interventions intended to ameliorate the conflict in the frontier region and support the forestry industry.

\section{DOUBLE MOVEMENT AND REACTIONS OF SOCIAL PROTECTION}

Polanyi's idea of movement and counter-movement sheds light on the contentious nature of the Chilean forestry sector, as well as the diverse social protection strategies used by different groups to shield themselves from the damaging impacts of market capitalism. As a market economy, in Polanyi's terms, capitalism is an economic system exclusively guided by market prices in which labor, land, and money are treated as commodities. "Disembedded" markets, however, can generate human pauperization and financial instability, negative consequences that the market alone is unable to correct. According to Polanyi, the commodification of labor, land, and money produce such corrosive tendencies that spontaneous reactions of "social protection" become inevitable. Once market capitalism attempts to separate itself from the social realm, protectionism is society's natural response. "No society could stand the effects of such a system of crude fictions for the shortest stretch of time unless its human and natural substance as well as its business organization was protected against the ravages of this satanic mill" (Polanyi, 2001: 77). 
A "double movement" governs the dynamic of capitalist societies, Polanyi explains. Two antagonistic organizational principles vie with each other: economic liberalism and social protection. While the former aims to establish "a self-regulating market, relying on the support of the trading classes, and using largely laissez-faire and free trade as its methods," the latter aims at "the conservation of man and nature as well as productive organization, relying on the varying support of those most immediately affected [...] using protective legislation, restrictive associations, and other instruments of intervention as its methods" (Polanyi, 200I: I39). If an unrestrained free market is imposed, then social protectionism will be the spontaneous reaction to the dislocation it produces. This "collectivist" counter-movement appears in a great variety of forms. No single group or class comprises its source (Polanyi, 20I2). What generate these social reactions, ultimately, are the broad range of vital social and cultural interests affected by the expanding market mechanism.

Conflicts in the frontier region can be read not only as territorial disputes, but as reactions of social protection, opposing capitalist pressures to commercialize land and labor, while defending cultural institutions and ways of living instigated by the various groups that surround the forest industry and are labelled under the generic concept of "peasants." These reactions have taken different forms over time but present a common pattern. In the early twentieth century, for example, peasants claimed to ascribe to Chile's Colonization Law by invading private or state lands and claiming to have worked them. Burning forests, fencing the land, and planting wheat were ways to produce evidence of land usage either to obtain settler deeds or to support indigenous land claims. Likewise, the peasant revolts of the I920s and I930s on the frontier were concerted reactions of social protection, in defense of access to native forests and in demand of better living conditions under inquilinaje (tenancy). ${ }^{5}$ The most iconic of these revolts was the Ránquil Uprising. In I 934 the peasants of Ránquil State in Lonquimay rose in arms against the farm stewards (Klubock, 2014: 94). Carabineros (the Chilean police) stifled the rebellion after ten days. Many peasants and Mapuche were chained and marched to Temuco, while over 30 people were killed and disappeared. A similar reading can be made of the significant increase in land invasions during the UP government. Land invasions gained momentum at the end of the ig6os with the agrarian reform and peasant popular movements. The counter reaction of Pinochet's dictatorship after I 973 was to abolish the peasants' law and agrarian reform, and to repress indigenous land claims. Waves of movements and counter-movements mark the dynamics between market advancements and society's attempts to seek protection.

With the significant expansion of the free-market forestry industry during the last 40 years, and the material, symbolic, and territorial conquest of the frontier through pines and eucalyptus, the social protection reactions of local communities have multiplied. Since the return to democracy, the Mapuche have 
linked their land claims to an environmentalist discourse, asking for land restitution to protect biodiversity and their traditional ways of life. Thanks to the Indigenous Law of I994, the Mapuche were able to recover territories, opening a new cycle of land conflict during the Ig9os (Pairicán, 20I4). The invasion of estates, blockading of roads and burning of logging trucks, churches, and schools continue until this day. Despite the different social protection reactions, forest legislation and indigenous mediation mechanisms have not been enough to contain the conflict in the frontier region.

\section{DISCUSSION}

This article has examined the current conflict between the forest industry and Mapuche communities in light of Karl Polanyi's postulates, contextualizing the Chilean State's long-standing difficulties in establishing control and promoting socially and environmentally sustainable development in the southern frontier. Notwithstanding the differences between the industrial revolution in seventeenth-century England and neoliberalism in twentieth-century Chile, both attempts to commodify land and labor generated large-scale social, environmental, and political dislocations in many of the ways Polanyi describes.

In the Chilean case, given immense industry pressure to exploit new lands (Cotula, 20I3), Mapuche communities have deployed various social protection mechanisms, both legally claiming indigenous lands through CONADI, as well as invading estates, blocking roads, and burning logging trucks. In an attempt to defuse the conflict, the Chilean State has bought several disputed lands and transferred them to Mapuche communities. In the Bío-Bío and Araucanía regions alone, I5I,6I9 hectares were transferred between 1994 and 2018 (CONADI, 20I9a). Yet despite the legal transfer of these lands, the conflict remains alive. It is interesting to note here how public awareness of Chilean society's debt to the Mapuche, and the depth of the conflict, have shifted from the Ig9os to today. While in the early Ig9os the institutional creation of CONADI and the disposition to buy land for indigenous communities was considered a great step forward, Mapuche leaders today expect more: not only the return of dispossessed lands, but also a cultural and political recognition of their place in history. Politically, this has led to the development of a new kind of identity politics, which may be seen in the demand for the Mapudungun language to be taught in local schools, for Mapudungun messages and signs to be posted in public spaces, and for the actions of dissidents branded "terrorist" to be reconsidered.

Notably, the last wave of counter-movements initiated in the I990s did not lead directly to a decline in the forestry industry's commodification of the frontier territory. Similar to Goodwin's (2018) findings in communities in Ecuador, reactions to commodification have not necessarily led to a re-embedding of the economy in society. Although the Mapuche are usually read as being 
more closely connected to nature, and therefore as having a stronger commitment to defending it (Di Giminiani, 20I8), it is worth avoiding essentialist readings of their approach to land. An essentialist reading not only leaves out the occupation history of the Mapuche before the Spanish invasion (Bengoa, 2008), but also marginalizes the dilemmas and practical activities that come with living in a territory marked by conquest (Di Giminiani, 2018: 88). The paradox for many Mapuche is that their traditional way of life forces them to live directly off the land, something they can increasingly do only by adopting the values and practices of the market economy that now dominates the relationship to the land where they live.

While the Mapuche land claims are linked to a legalistic grammar ( $\mathrm{Di}$ Giminiani, 20I8) traversed by poverty and violence, other hybrid reactions, such as indigenous ecotourism, show that alternative paths exist. The Mapuche community of Quinquén in Galletué is known for its forest management and sustainable use of Araucaria forests. The communities near Lican Ray and Picura studied by Skewes (2019) are other positive cases of ecotourism, in which Mapuche economic development and resistance discourses have come together in fruitful ways.

While Polanyi's analysis helps shed light on capitalism's advances and the waves of social protection manifested in the Chilean frontier region, this analysis also has its limitations with respect to the case at hand. This limitation is expressed in at least three ways. First, Polanyi assumes that social protection reactions against the market will be forceful and organized in defense of the collective. In the Mapuche case, however, although there are protection responses, there are also a series of hybridizations that overflow this logic. Moreover, while there are multiple territories that are highly conflictive today - Tirua, Temucuicui, Carahue, to name a few - there are also Mapuche entrepreneurs who have been integrated into the forestry sector as small pine producers. Just as there are Mapuche communities who have sought to repel the forestry industry and defend their connection to the territory, so others have joined the productive chain as subcontractors. Second, one might expect that, from Polanyi's perspective, social protection reactions would be organized in a more coherent way on behalf of all Mapuche communities, their institutions, and their cultural heritage. This has not been the case, though. Politically, the Mapuche are a nation-people who have had difficulties in articulating a unitary political defense against the Chilean State. While the lonkos or caciques are the chiefs or heads of Mapuche communities, they do not always succeed in organizing communities beyond their own local territory. The social protection reactions described by Polanyi involve a level of political development that enables the orchestration of the defense of common interests. Such a level of political development does not always occur among Mapuche communities in the frontier territory. 
Third, regardless of Polanyi's negative reading about the market's role in society, in this case, paradoxically, market-driven certification mechanisms have been among the most successful initiatives to rebuild relationships among forestry industry actors - firms, subcontractors, communities, NGOs, and local authorities. The case of the Forest Stewardship Council (FSC) is telling. FSC is a private governance model launched in I 993 by different global NGOs aiming to regulate the forestry industry and protect native forest. It was built as a reaction to the failure of states to protect native forests worldwide. This council established standards of production and certification that encourage the industry to maintain good practices of benefit to local communities and the environment. The wood certified by this standard is traceable and has greater economic value. The FSC grew rapidly worldwide during its early years (Auld, 20I4), yet it was strongly rejected by the Chilean forestry industry. Things started to change in 2002 when The New York Times called for a boycott of Chilean wood products because they were produced by an industry that replaces native forests with monoculture plantations (Tricallotis, 20I6). After a decade of slowly ceding ground, the main forestry players (Arauco and CMPC) incorporated the FSC standards in 20I2. Even though the FSC's power to transform and regulate the forest industry is limited (Moog, Spicer \& Böhm, 20I5), incorporating external standards of production has pushed the Chilean industry to adopt new ways of relating with actors and stakeholders. Today the FSC has managed to certify more than 2.3 million hectares of plantations as environmentally, socially, and economically sustainable, which has transformed relationships between companies (CMPC and Arauco), civil society (environmentalists, unions) and local communities, beyond the State's mediation (Tricallotis, 2016). What the Chilean State was not able to tame - an industry with too much structural and instrumental power - a market-coordinated initiative has thus managed to curb to some degree.

The Chilean forestry industry has a clear desire to look to the future and overcome the environmental and social frictions on which it rests. It generally presents itself as an internationally certified "green" industry (Henne, 20I5), whose production helps reduce the country's carbon footprint. The CORMA logo today is green leaves, under the slogan "Renewable resources" and "Forests for Chile." The CORMA logo until I960 was an Araucaria pine tree circled by a chainsaw blade. The current slogan clearly denies the environmental impacts of its plantations, especially the destruction of native forests on which they depended. Despite recent efforts of large forestry companies (Arauco and CMPC) to move "closer" to local communities, friction, and distrust with indigenous populations remains alive in some areas. A recognition of the industry's controversial history, including its role in logging native forests, and a more balanced assessment of the environmental impacts of monoculture plantations would be vital steps to restore trust within the frontier region. Its purely eco- 
nomic justification as an industry that generates multiple jobs, produces a material vital for subsistence, and drives economic growth, are not enough. The forestry sector would also benefit from recognizing the historical role played by the State in its development, which would go hand-in-hand with recognizing the State's right to regulate its future development.

There is hope of better relationships in the frontier region, both because of the industry's better practices and because of the State's efforts to begin repaying its debts to the Mapuche people. However, the structural relationships between Mapuche communities, the forestry industry and the Chilean state remain extremely unbalanced in terms of economic power, political influence, and cultural recognition. Until these structural imbalances are ameliorated, the conflict in the frontier territory is likely to continue.

Received on 09/Feb/2020 | Revised on 03/Aug/2020 | Approved on 20/Oct/2020

Tomás Undurraga ( $\mathrm{PhD}$, University of Cambridge) is associate professor at the Department of Sociology, Universidad Alberto Hurtado, Chile.

His research interests intersect cultural and economic sociology, expert knowledge and media studies. His empirical research has focused on the making of the public economic sphere in Argentina, Brazil and Chile, and knowledge production in climate science. He has published in journals such as Cultural Sociology, The Sociological Review, Journal of Cultural Economy, Journalism Studies, Revista de Sociologia e Política, among others.

Felipe Márquez is master in sociology from Universidad Alberto Hurtado. His research is focused on social movements, economic sociology and environmental certification. He currently works as an academic in the Sociology Department of Universidad the Alberto Hurtado, and as a research assistant in the project "Incendios Forestales y 


\section{NOTAS}

I We would like to thank the guest editors of this special issue and the two anonymous reviewers for their insights and comments, which improved this article. The authors also thank the participants at the 2019 workshop "Incendios forestales y nuevo régimen climático: interrogando agendas de investigación" at Universidad Alberto Hurtado and the VII Encuentro Anual de la Red CTS-Chile 2020, where earlier versions of this paper were presented. We especially thank Sasha Mudd for her English proofreading. The research for this paper was supported by the National Research and Development Agency (ANID) under FONDECYT Grant number III806II. Tomas Undurraga also thanks the support of Anillo Conicyt-PIA SOCi80039.

2 Dillehay (2016) argues that in the 250 years of the Arauco War, the Spanish recognized an Indomitable State south of the Bío-Bío. For Dillehay, the use of the word State is indicative of Araucanian sovereignty, a networking arrangement of trans-territorial, supra-ethnic, and inter-institutional leaders.

3 While the average proportion of the population living in poverty in Chile is $8.7 \%$, in the Araucanía region it is $17.2 \%$ and in the Bío Bío region I2.3\% (Ministerio de Desarrollo Social, 2018). Within these regions, the indigenous population living in poverty is $26.35 \%$ and $18.26 \%$, respectively (CONADI, 20I9a, 20Igb).

4 Araucanía has a total area of 3,180,348 hectares, 964,I53 hectares of which correspond to native forest versus 482 , I 3 hectares of forest plantations. The Bio-Bío Region has a total of 3,703,00I hectares of land, 845,552 hectares of which are native forest versus 913,173 hectares of forest plantations (INFOR, 20I9).

5 For the particular ways in which the inquilinaje system worked in the frontier region, see Klubock (2014).

\section{BIBLIOGRAPHY}

Almonacid, Fabián. (2009). El problema de la propiedad de la tierra en el sur de Chile (I850-I930). Historia, I, p. 5-56. 
Altamirano, Adison et al. (2013). Influencia de la heterogeneidad del paisaje en la ocurrencia de incendios forestales en Chile Central. Revista Geografía Norte Grande, 55, p. I57-I70.

Andersson, Krister et al. (2016). More trees, more poverty? The socioeconomic effects of tree plantations in Chile, 200I-20II. Environmental Management, 57/I, p. I23-136.

Auld, Graeme. (20I4). Constructing private governance. The rise and evolution of forest, coffe, and fisheries certification. New Haven: Yale University Press.

Beckert, Jens. (2007). The great transformation of embeddedness: Karl Polanyi and the new economic sociology. MPifG Discussion Paper, 7/I.

Bengoa, José. (2008). Historia del Pueblo Mapuche. Siglos XIX y XX. Santiago: LOM.

Bengoa, José. (1992). Quinquén: ıoo años de historia Pehuenche. Santiago: LOM.

Block, Fred \& Evans, Peter. (2005). The State and the economy. In: Neil, J. Smelser \& Swedberg, Richard (eds.). The Handbook of Economic Sociology. Princeton: Princeton University Press, p. 505-526.

Boccara, Guillaume \& Seguel-Boccara, Ingrid. (I999). Políticas indígenas en Chile (siglos XIX y XX). De la asimilación al pluralismo (el caso mapuche). Revista de Indias, 59/2I7, 74I-774.

Camus, Pablo. (2006). Ambiente, bosques y gestión forestal en Chile. I54I-2005. Santiago de Chile: Ediciones de la Dirección de Bibliotecas, Archivos y Museos/LOM.

CONADI. Corporación Nacional de Desarrollo Indígena. (20I9a). Región del Biobío Estadísticas Sociales. Retrieved from http://siic.conadi.cl/tmp/obj_424I63/25833_Región del Biobío (3).pdf.

CONADI. Corporación Nacional de Desarrollo Indígena. (20Igb). Región de La Araucanía Estadísticas Sociales. Retrieved from http://siic.conadi.cl/tmp/obj_6or447/25836_ Región de La Araucanía 2019 (5).pdf.

CONAF Corporación Nacional Florestal. (2016). Superficies catastros y usos de suelos y recursos vegetacionales. Departamento de Monitorio de Ecosistemas Forestales. http://sit.conaf.cl. 
Cotula, Lorenzo. (2013) The great African land grab? Agricultural investments and the global food system. London/ New York: Zed Books.

Dale, Gareth. (2010). Karl Polanyi. Cambridge: Polity Press. Di Giminiani, Piergiorgio. (2018). Sentient lands. Indigeneity, property and political imagination in neoliberal Chile. Tucson: University of Arizona Press.

Dillehay, Tom D. (20I6). Reflections on Araucanian/Mapuche resilience, independence, and ethnomorphosis in colonial (and present-day) Chile. Chungara, 48/4, p. 69I-702. Domingues, José Maurício. (2008) Latin America and contemporary modernity. London: Routledge.

Elizalde Mac-Clure, Rafael. (I970). La sobrevivencia de Chile. La conservación de sus naturales renovables. Santiago de Chile: Ministerio de Agricultura.

Feinig, Jakob. (2018). Beyond double movement and re-regulation: Polanyi, the organized denial of money politics, and the promise of democratization. Sociological Theory, 36/I, p. 67-87.

Foerster, Rolf \& Montencino, Sonia. (I988). Organizaciones, lideres y contiendas mapuches (I900-I970). Santiago: Centro de Estudios de la Mujer.

Foerster, Rolf \& Vergara, Jorge Iván. (2002). Permanencia y transformación del conflicto mapuche. Revista Austral de Ciencias Sociales, 6, p. 35-46.

Gemici, Kurtulus \& Nair, Manjusha. (2016). Globalization and its countermovement: marxian contention or polanyian resistance? Sociology Compass, I0/7, p. 580-59I.

Germani, Gino. (I98I). The sociology of modernisation. Studies on its historical and theoretical aspects with special regards to the Latin American case. New Brunswick, NJ: [s.n.].

González, Mauro et al. (2020). Incendios forestales en Chile. Causas, impactos y resiliencia. [s.l.]: Centro del Clima/ Resiliencia (CR)2/Universidad de Chile/Universidad de Concepción/Universidad Austral de Chile.

Goodwin, Geoff. (2018). Rethinking the double movement: expanding the frontiers of polanyian analysis in the global south. Development and Change, 49/5, p. I268-I290. 
Granovetter, Mark. (I985). Economic action and social structure: the problem of embeddedness. American Journal of Sociology, 9I/3, p. 48I-5IO.

Granovetter, Mark \& Swedberg, Richard (eds.). (I992). The handbook of economic sociology. Princeton: Princeton University Press.

Halperin, Sandra. (2018). Polanyi's two transformations revisited: a 'bottom up' perspective. Globalizations, I5/7, p. 9II-923.

Hart, Gillian. (200I). Development critiques in the I99os: culs de sac and promising paths. Progress in Human Geography, 25/4, p. 649-658.

Henne, Adam. (2015). Environmentalism, ethical trade, and commodification. Technologies of value and the Forest Stewardship Council in Chile. New York: Routledge.

INFOR. (20I9). Estadísticas Forestales Regionales. Retrieved from https://wef.infor.cl/estadisticas_regionales/ estadisticasregionales.php.

Klubock, Thomas Miller. (2014). La Frontera: forests and ecological conflict in Chile's frontier territory. Durham: Duke University Press.

Kurtz, Marcus. (200I). State developmentalism without a developmental State: the public foundations of the 'free market miracle' in Chile. Latin American Politics and Society, 43/2, p.I-25.

Lima-Toivanen, Maria Barbosa. (2012). The South American pulp and paper industry: the cases Brazil, Chile, and Uruguay. In Lamberg, Juha-Antti et al. (eds.). The evolution of global paper industry I800-2050. Ebook.

Li, Tania Murray. (2010). Indigeneity, capitalism, and the management of dispossession. Current Anthropology, 5I/3, p. 385-4I4.

Lopez, Sandra \& Nitrihual, Luis. (20I4). Vidas de papel. Temuco: Editorial Universidad de la Frontera.

Mapuche Data Proyect. (20I9). Base de datos MACEDA. Retrieved from http://mapuchedataproject.cl/datos-de-conflicto/.

Mathews, Andrew S. (20II). Instituting Nature. Authority, expertise and power in Mexican forest. Cambridge: MIT Press. 
Ministerio de Desarrollo Social. (2018). Encuesta de caracterización socioeconómica nacional. Retrieved from http:// observatorio.ministeriodesarrollosocial.gob.cl/casen.

Moog, Sandra; Spicer, André \& Böhm, Steffen. (20I5). The politics of multi-stakeholder initiatives: the crisis of the Forest Stewardship Council. Journal of Business Ethics, I 28/3, p. 469-493.

Nazer, Ricardo; Camus, Pablo \& Muñoz, Ignacio. (2009). Historia de la Corporación de Fomento de la Producción. Santiago de Chile: CORFO.

Nazif, Iván. (20I4). Plantaciones y pobreza en comunas forestales. Forestación y estilo de desarrollo. Santiago: Corporación Nacional Forestal.

ODEPA. (20I2). Estadísticas forestales. Serie histórica I99020I2. Retrieved from https://www.odepa.gob.cl/wp-content/uploads/2013/ıo/Estadísticas-Forestales.xlsx.

Pairicán, Fernando. (20I4). Lumaco: la cristalización del movimiento autodeterminista mapuche. Revista de Historia Social y de Las Mentalidades, I7/I, p. 35-59.

Pineda, César Enrique. (2014). Mapuche: resistiendo al capital y al Estado. El caso de la Coordinadora Arauco Malleco en Chile. Latinoamérica. Revista de Estudios Latinoamericanos, 59, p. 99-128.

Pinto, Jorge. (2012). El conflicto Estado-pueblo mapuche I900-1960. Universum, I, p. I67-189.

Polanyi, Karl. (2012). A subsistência do homen. E ensaios correlatos. Rio de Janeiro: Contraponto.

Polanyi, Karl (200I) [1944]. The great transformation: the political and economic origins of our time. Boston: Beacon Press.

Sandbrook, Richard. (20II). Polanyi and post-neoliberalism in the global south: dilemmas of re-embedding the economy. New Political Economy, I6/4, p. 4I5-443.

Scott, James C. (1998). Seeing like a State. How certain schemes to improve the human condition have failed. New Haven: Yale University Press.

Skewes, Juan Carlos. (2019). La regeneración de la vida en los tiempos del capitalismo. Otras huellas en los bosques nativos del centro y sur de Chile. Santiago de Chile: Ocho Libros 
Smith, Adam. (1986) [1776]. The wealth of nations. Harmondsworth: Penguin Classic.

Svampa, Maristella. (2013). Consenso de las commodities. Nueva Sociedad, 244, p. 30-46.

Taylor, Marcus. (2006). From Pinochet to the Third Way: neoliberalism and social transformation in Chile. London: Pluto Press.

Torres-Salinas, Robinson et al. (2016). Forestry development, water scarcity, and the mapuche protest for environmental justice in Chile. Ambiente e Sociedade, I9/I, p. I 2 I-I 44 .

Tricallotis, Marcos. (2016). ¿En qué contexto surge la certificación forestal en Chile? desempeño ambiental, social y económico de empresas no certificadas. Bosque, 37/3, p. 613-624.

Trigilia, Carlo. (2002). Economic sociology. State, market, and society in modern capitalism. Hoboken: Blackwell Publishers. Tsing, Anna Lowenhaupt. (2005). Friction. An ethnography of global connection. New Jersey: Princeton University Press. Undurraga, Thomas. (2015). Neoliberalism in Argentina and Chile: common antecedents, divergent paths. Revista de Sociologia e Política, 23/55, p. I I-34.

Undurraga, Thomas. (2014). Divergencias: trayectorias del neoliberalismo en Argentina y Chile. Santiago de Chile: Ediciones Universidad Diego Portales. 
Palavras-chave Indústria florestal;

Mapuche; Estado chileno; contramovimento; proteção social; Polanyi.

Keywords Forestry industry; Mapuche; Chilean State; counter-movement; social protection; Polanyi.
THE UNFINISHED DEVELOPMENT OF THE FRONTIER: A KARL POLANYI READING OF THE CONFLICT BETWEEN THE FORESTRY INDUSTRY, MAPUCHE COMMUNITIES AND THE CHILEAN STATE

\section{Resumo}

O artigo explora conflitos entre a indústria florestal, as comunidades Mapuche e o Estado chileno à luz da leitura de Polanyi sobre a expansão capitalista. Oferece análise histórico-institucional das maneiras pelas quais o Estado chileno usou a florestação para domar uma fronteira selvagem e os povos nativos que ali vivem. Argumenta que o aumento da violência nessa zona responde à crescente militarização do Estado na área e reflete o contramovimento de proteção social iniciado pelo povo Mapuche - contra uma indústria florestal de livre mercado que transformou a paisagem, limitando o acesso dos Mapuche a terras e florestas, e contra um processo de modernização liderado pelo Estado chileno que corroeu as instituições tradicionais dos Mapuche e lhes ofereceu integração em termos desiguais, como "campesinos pobres".

THE UNFINISHED DEVELOPMENT OF THE FRONTIER: A KARL POLANYI READING OF THE CONFLICT BETWEEN THE FORESTRY INDUSTRY, MAPUCHE COMMUNITIES AND THE CHILEAN STATE

Abstract

This article explores conflicts between the forestry industry, Mapuche communities and the Chilean State in light of Polanyi's reading of capitalist expansion. It offers a historical-institutional analysis of the ways in which the Chilean State used afforestation to tame a wild frontier and the native people living there. We argue that the rise of violence in this zone responds to the State's growing militarization of the area and reflects the counter-movement of social protection initiated by the Mapuche people - both against a free-market forestry industry that has transformed the landscape, limiting Mapuche access to lands and forests, and a modernization process led by the Chilean State that eroded traditional Mapuche institutions and offered them integration on unequal terms as "poor peasants." 